\title{
Effect of ultraviolet radiation on plant biochemical properties
}

\author{
(C) Valery N. Zelenkov, ${ }^{1,2,4}$ Anatoly A. Lapin, ${ }^{3 *^{+}}$ \\ Vyacheslav V. Latushkin, ${ }^{4}$ and Vladimir. V. Karpachev ${ }^{5}$ \\ ${ }^{1}$ All-Russian Scientific Research Institute of Vegetable Growing Vegetables is a Branch of the Federal \\ Research Center for Vegetable Growing - the Branch of FSBSI "Federal Scientific Vegetable Center"500 \\ Vereya Village. Ramenskoe District. Moscow Region, 140153.Russia.E-mail: ivanova_170@mail.ru \\ ${ }^{2}$ All-Russian Scientific Research Institute of Medicinal and Aromatic Plants. \\ Greene St., 7. Moscow, 117216.Russia.E-mail: zelenkov-raen@mail.ru \\ ${ }^{3}$ ANO Development Strategies Institute, St. Red Proletarian, 16, Under. 5. \\ Moscow, 125319.Russia.E-mail: slavalat@yandex.ru \\ ${ }^{4}$ Department of Water Bioreservices and Aquaculture. Kazan Energy University. Krasnoselskaya St., 51. \\ Kazan, 420066. Republic of Tatarstan. Russia.Phone: +7 (843) 519-42-67. E-mail: lapinanatol@mail.ru \\ ${ }^{5}$ All-Russian Scientific Research Institute of Rapeseed. Lipetck, 398037. Boevoy Ave., 26. Russia. \\ E-mail: karpachevv@gmail.com
}

*Supervising author; ${ }^{+}$Corresponding author

Keywords: seeds, sprout, microzelenium, antioxidant properties, seed germination, germination energy, germination, nougat, sugar beets, ultraviolet radiation.

\section{Abstract}

Depletion of the ozone layer leads to increased ultraviolet radiation, which affects the growth and functioning of plants and leads to their various physiological, biochemical, morphological and ultrastructural changes. When studying the effect of ultraviolet radiation on seed sowing qualities and biometric indicators of morphological organs of plants of various cultures, scientists did not come to a consensus on the optimal parameters of its effects. For seeds of each plant variety, there is an optimal amount of energy absorbed, resulting in a maximum effect. Ecologically significant low ultraviolet radiation changes the metabolism of reactive oxygen species and plant antioxidant systems by increasing enzyme regulation. The relevance of studies in this direction is obvious, as it allows you to stimulate the germination of seeds with physical influences, increasing their laboratory and field germination. The authors obtained and published new data on comparison of sown, crop and antioxidant properties of seeds and seedlings, seed viability, microzelenium biomass formation and change of total antioxidant activity of vegetable crops after thermodehydration. As a continuation of these studies, the purpose of this work was to study the effect of ultraviolet radiation on the biochemical properties of plants. The total antioxidant activity of sugar beet and nougat sprouts in the experiment increased under the influence of stress ultraviolet radiation. Compared to control samples (germination according to GOST in the dark), under the influence of ultraviolet radiation, antioxidant activity increases by $11.4-17.4 \%$ otn. Ultraviolet radiation is damaging factors of plant growth and development, which is manifested at different stages of ontogenesis. Thus, sowing properties are reduced (germination of sugar beet seeds is less than control by $18 \%$, in nougat seeds by $12 \%$ ), above-ground biomass at the end of the germination period is less by $49.0 \%$ in sugar beet and by $16.5 \%$ in Abyssinian nougat. Resistance to the damaging effects of ultraviolet radiation depends on the genetic nature of the plant: in the experiment, the sprouts of the Abyssinian nuga turned out to be more resistant.

\section{References}

[1] Z. Rutao, H. Guangrong, W. Lihong, Z. Qing, H. Xiaohua. Effects of elevated ultraviolet-B radiation on root growth and chemical signaling molecules in plants. Ecotoxicology and Environmental Safety. 2019. Vol.17130. P.683-690.

[2] J. Deepanshi, P. Avantika, M. Arideep, A. Madhoolika, B.A. Shashi. Alterations in growth, antioxidative defense and medicinally important compounds of Curcuma caesia Roxb. under elevated ultraviolet-B radiation. Environmental and Experimental Botany. 2020. Vol.177. Article 104152.

[3] E.V. Garmash, I.O. Velegzhaninov, K.V. Ermolina, A.V. Rybak, R.V. Malyshev. Altered levels of AOX1a expression result in changes in metabolic pathways in Arabidopsis thaliana plants acclimated to low dose rates of ultraviolet B radiation. Plant Science. 2020. Vol.291. Article 110332. 
[4] N. Mehrdad, Z. Fatemeh. Ultraviolet-B induced changes in Mentha aquatica (a medicinal plant) at early and late vegetative growth stages: Investigations at molecular and genetic levels. Industrial Crops and Products. 2020. Vol.15415. Article 112618.

[5] Yu.V. Tertyshnaya, N.S. Levina, O.V. Elizarova. Impact of ultraviolet radiation on germination and growth. Cand. Sci.(Chem.). 2017. No.2. P.31-36. DOI: https://doi.org/10.22314.2073-7599-2017.2.31-36

[6] E.V.A. Marcos, G.B. Eloiny, S.LA. Rodrigo. Physiological and sanitary quality of castor oil plant seeds due to ultraviolet-C radiation. Industrial Crops and Products. 2020. Vol.1371. P.9-15.

[7] I.P. Okokpujie, U.C. Okonkwo, O.S.I. Fayomi, G.B. Dirisu. Data on physicochemical properties of borehole water and surface water treated using reverse osmosis [RO] and ultra-violet [UV] radiation water treatment techniques. Chemical Data Collections. 2019. Vol.20. Article 100207.

[8] A.Yu. Khudyakova et al. Impact of UV-B radiation on the photosystem II activity, pro- /antioxidant balance and expression of light-activated genes in Arabidopsis thaliana hy4 mutants grown under light of different spectral composition. Journal of Photochemistry and Photobiology. B: Biology. 2019. Vol.133. DOI: https://doi.org/10.1016/j.jphotobiol.2019.02.003

[9] V.D. Kreslavski et al. Effect of preillumination with red light on photosynthetic parameters and oxidant-/ antioxidant balance in Arabidopsis thaliana in response to UV-A. Journal of Photochemistry and Photobiology. B: Biology. 2013. Vol.127. P.229-236.

[10] V.D. Kreslavski et al. Response of photosynthetic apparatus in Arabidopsis thaliana L. mutant deficient in phytochrome A and B to UV-B. Photosynthetica. 2018. Vol.56. P.418-426. DOI: https://doi.org/10.1007/s11099-017- 0754-8

[11] L. Dyshlyuk, O. Babich, A. Prosekov, S. Ivanova, T. Chaplygina. The effect of postharvest ultraviolet irradiation on the content of antioxidant compounds and the activity of antioxidant enzymes in tomato. Heliyon. 2020. Vol.6. No.1. Article e 03288.

[12] L. Panjai, G. Noga, A. Fiebig, M. Hunsche. Effects of continuous red light and short daily UV exposure during postharvest on carotenoid concentration and antioxidant capacity in stored tomatoes. Scientia Horticulturae. 2017. Vol.22619. P.97-103.

[13] V.A. Savelyev, O.A. Kurochkina. Method of pre-treatment of wheat seeds. Patent of the Russian Federation 238305. A 01C 1/00. Published 2008.03.10.

[14] V.N. Zelenkov, Maria I. Ivanova, V.V. Latushkin, and A.A. Lapin. Yield and antioxidant activity of microgreens Petroselinumcrispum. Butlerov Communications. 2020. Vol.61. No.3. P.99-104. DOI: 10.37952/ROI-jbc-01/20-61-3-99

[15] V.N. Zelenkov, V.V. Latushkin, A.A. Lapin, and V.M. Kosolapov. Comparison of the sowing, harvesting and antioxidant properties of seeds and seedlings of a giant field moth (Agrostis gigantea Roth) after air drying and thermal dehydration. Butlerov Communications. 2020. Vol.61. No.3. P.120125. DOI: $10.37952 / \mathrm{ROI}-\mathrm{jbc}-01 / 20-61-3-120$

[16] V.N. Zelenkov, А.A. Lapin. МВИ-001-44538054-07. Total antioxidant activity. Method of measurement on the coolometric analyzer. VNII Vegetable Growing. Verea, Moscow Region. 2013. 19p. (russian) 